\title{
KNOWLEDGE AND ATTITUDE OF MOTHERS TOWARDS MEASLES AND MEASLES, MUMPS AND RUBELLA (MMR) VACCINE IN IDI- ABA COMMUNITY ABEOKUTA, NIGERIA
}

\author{
${ }^{* 1}$ Oluseye, O. M., ${ }^{2}$ Jimoh, N. A. \& ${ }^{3}$ Ogunleye, C. A.
}

\author{
${ }^{* 1,2 \& 3}$ School of Nursing, Ilaro, Ogun State, Nigeria \\ *Corresponding author Email: oluseye.mary@gmail.com,olubim4real@yahoo.com,abosedenusirat59@gmail.com \\ Phone: +2348061529484
}

\begin{abstract}
Measles has remained endemic in some part of the world where the vaccine is not easily accessible. Although vaccine is available in some parts of the world, with routine immunization services and campaigns, many children are yet to be vaccinated. Hence, this study assessed the knowledge and attitude towards measles and Measles, Mumps and Rubella vaccine (MMR) among mothers in Idi-aba community. This was a descriptive research design using multistage sampling technique to select participants for the study. A self-constructed questionnaire was used to collect information from participants. After the distribution and collection of the questionnaires, data was analyzed using descriptive statistics. Results showed that 93.2\% (386) and 65.9\% (273) participants indicated that they knew what measles and MMR vaccines are respectively. However, overall analysis revealed that only 165 (39\%) participants had high knowledge of measles and MMR vaccine while 303 (74\%) had good attitude towards measles and MMR vaccine. This study showed that there are some knowledge gaps. Factors significantly associated with high percentage of mothers having good attitude are occupation $(\chi 2=20, \mathrm{P}=0.000)$, income $(\chi 2=5.9$, $\mathrm{P}=0.009)$ and parity $(\chi 2=23, \mathrm{P}=0.000)$. In conclusion, this result implies that in order to sustain the good attitude displayed by the mothers, there is need for strategic intensive health educational programs for the mothers of the community.
\end{abstract}

Keywords: Attitude, Immunization, Knowledge, Measles, MMR Vaccine, Mothers

LICENSE: This work by Open Journals Nigeria is licensed and published under the Creative Commons Attribution License 4.0 International License, which permits unrestricted use, distribution, and reproduction in any medium, provided this article is duly cited.

COPYRIGHT: The Author(s) completely retain the copyright of this published article.

OPEN ACCESS: The Author(s) approves that this article remains permanently online in the open access (OA) model.

QA: This Article is published in line with "COPE (Committee on Publication Ethics) and PIE (Publication Integrity \& Ethics)". 


\section{INTRODUCTION}

Infectious diseases are responsible for most morbidity and mortality among children. These diseases can be prevented through effective vaccination. Vaccination is cheap and safe than treating diseases and disabilities that may result from the infectious diseases (Ramadan et al., 2016). Measles is one of the infectious and contagious viral diseases that are responsible for high mortality rate among young children globally despite availability of effective and safe vaccine (Geier, 2014). Vaccination has drastically reduced global measles death, but measles is still common in many developing countries particularly in Africa and Asia (World Health Organization, 2019).

Measles majorly affects the respiratory tract and is transmitted by direct contact with respiratory droplets from the nose, mouth or throat of an infected person or airborne spread between person to person (Geier et al., 2019). Measles often presents with high fever, cough, runny nose, and watery eyes and this last for about $7-14$ days (Centre for Diseases Control (CDC), 2021). If this disease is not treated on time it could result into serious complications such as pneumonia and encephalitis (Higuera, 2019). Measles, mumps, and rubella (MMR) vaccine is a combined live attenuated vaccine used in preventing three deadly diseases of which measles is among (Taiwo, et al.,2018).

MMR vaccine was created in 1971 by Maurice Hillemanat at the Merck Institute of Therapeutic Research, a pharmaceutical company in West Point, Pennsylvania (Ross, 2017). MMR vaccine can be administered both to children and adults. MMR vaccine has tremendously helped in reduction of disability and death among children less than five in developed countries however this is still on the high side in developing countries. Low vaccination coverage is one among the major factor responsible for high morbidity and mortality rate among children in developing countries (Abebe, 2019). The vaccine is part of WHO expanded program on immunisation which Nigeria is among nations that has adopted the program (Adedokun et al., 2017). Highest number of reported cases worldwide on measles in 23 years was recorded in 2019. Global measles death reached nearly 50\% since 2016, claiming an estimated 207,500 lives in 2019 alone (World health organization, 2020). This was reported to occur due to failure to vaccinate children on time with two doses of measles vaccine.

In Nigeria, the National Program on Immunisation recommended two doses of MMR vaccine for every child. In order to ensure effective delivery of this vaccine, care givers and mothers were offered immunisation card for keeping record of vaccines administered. Despite all these efforts, report revealed that the prevalence of measles in Nigeria is still on the increase (Taiwo, et al. 2018). Nigeria is among the African countries that accounts for $94 \%$ of global deaths as a result of measles (Ibrahim et al., 2017). Most Nigerian children do not get immunised neither complete their immunisation schedule for so many reasons. A survey carried out in "Abeokuta, Ogun State in 2015 revealed that the surviving infant protection level due to measles vaccination was well over $100 \%$ however there was backlog of unimmunised children across 20 local governments areas" (Taiwo, et al. 2018). Many mothers still lack knowledge on measles and this has significantly affected their attitude towards its vaccine (Verulava, et al. 2019). Increasing mothers' knowledge will help in correcting their attitude thus improving their use of immunization services (Verulava, et al. 2019). The poor utilization of immunization services by mothers has been linked with some individual factors. The most significant factors among individual factors are knowledge, maternal education, source of information, certain beliefs, attitude to the use of health facility, among many others (Adedokun et al., 2017; Zahraei et al.,2017). It is against this background the researchers assessed the knowledge and attitude towards measles and MMR vaccine among mothers in Idi- Aba community Abeokuta. 


\section{AIM AND OBJECTIVES}

The aim and objectives of the study was to assess the knowledge and attitude towards measles and MMR vaccine among mothers in Idi- Aba community Abeokuta.

\section{JUSTIFICATION}

Findings of this study will provide stakeholders with clues that can help to reduce preventable child mortality and morbidity associated with measles by identifying knowledge gaps in this area.

\section{MATERIALS AND METHODS}

The study adopted descriptive research design and involved mothers who are resident in Idi-aba community, Abeokuta, Ogun state, Nigeria. Idi-Aba is the largest ward in Abeokuta South Local Government Area and also housed the major health care settings in Abeokuta. The community total population was estimated from the available data of total population of Abeokuta South Local Government Area which is 16,525 (Brinkchoff, 2020). Sample size for this study was 414 and this was obtained using Cochran's formula due to large population (Isreal, 2003).

Multi stage sampling technique was used in selecting mothers at community level. A self well-constructed questionnaire was used in collecting information from respondents. The validity of the research questionnaire was done by employing content validity technique. The questionnaire was given to expert for critiquing and suggestions. The corrections that were made were considered and carefully followed. A pilot study was carried out and the reliability of research questionnaire was established through test re test reliability method which measures internal consistency. After analysis, the level of reliability of the test was 0.736 .

Researchers together with trained assistants collected information from each participant in their house using aself-well-constructed questionnaire. After the distribution and collection of the questionnaires (414), data were sorted manually and analysed using statistical package for social sciences. Responses to questions were analysed using descriptive statistics frequency, percentages, charts and Mean \pm SD. Maximum obtainable score on knowledge is 14 while minimum obtainable score is 0 . Mean \pm SD was used in categorizing the results into high knowledge and low knowledge. Respondents that scored above the mean \pm SD score were categorized under high knowledge while those with score below the mean \pm SD were categorized under low knowledge. Total number of test items on attitude is 18 . The questions were both negatively and positively worded. Positive questions were scored as follow Agreed -2, Uncertain - 0 Disagreed -1, Negative questions in this section were reversed coded. Mean \pm SD score was also used to categorize into good and bad attitude. Respondents that scored above the mean \pm SD score were categorized as good attitude while those with score below the mean \pm SD were categorized as bad attitude.

Ethical Review

Ethical approval was collected from the Ethical Review Board Committee at Federal medical Centre and the Ethical Review number is NHREC/08/10-2015. The purpose of the study was explained to each respondent and verbal informed consent was also obtained from all respondents prior to administration of questionnaire. 


\section{RESULTS}

Table 1 showed the socio demographic distribution of the mothers that participated in the study, the mean age of respondents is 31.7 years. Most of the women were Christians 265 (64\%) and Yoruba 364 (87.9\%).

Table 1: Socio-demographic of Mothers

\begin{tabular}{|c|c|c|}
\hline Variables & $\begin{array}{l}\text { Frequency } \\
\mathrm{N}=414\end{array}$ & Percentages \\
\hline \multicolumn{3}{|l|}{ Age } \\
\hline$<30$ years & 225 & 54.3 \\
\hline $31-40$ years & 139 & 33.5 \\
\hline $41-50$ years & 39 & 9.4 \\
\hline$>50$ years & 11 & 2.2 \\
\hline \multicolumn{3}{|c|}{ Educational status } \\
\hline No education & 10 & 2.4 \\
\hline Primary & 26 & 6.3 \\
\hline Secondary & 160 & 38.6 \\
\hline Tertiary & 218 & 52.7 \\
\hline \multicolumn{3}{|l|}{ Occupation } \\
\hline Trader & 132 & 31.9 \\
\hline Artisans & 93 & 22.5 \\
\hline Professionals & 102 & 24.6 \\
\hline Self employed & 20 & 4.8 \\
\hline Students & 37 & 8.9 \\
\hline Housewives & 30 & 7.2 \\
\hline \multicolumn{3}{|l|}{ Income status } \\
\hline Low income & 270 & 65.2 \\
\hline High income & 144 & 34.8 \\
\hline \multicolumn{3}{|l|}{ Parity } \\
\hline $1-2$ & 266 & 64.3 \\
\hline $3-4$ & 125 & 30.9 \\
\hline $5-6$ & 23 & 5.6 \\
\hline
\end{tabular}

\section{KNOWLEDGE ON MEASLES AND MMR VACCINE}

Table 2 and table 3 shows result of mothers' knowledge on Measles and MMR vaccine. The common signs of measles identified by mothers were fever 320(77.3\%), rashes 314 (75.8\%), loss of appetite 240(58.0\%), runny nose 157(37.9\%) however, only few had adequate knowledge of its complications. It was only conjunctivitis that had highest responses of 285 (68.8\%), others were 201(48.6\%) otitis media, 145 (35.0\%) dehydration and 98 (23.7\%) pneumonia. Furthermore, 272(66.5\%) of mothers indicated they knew what MMR vaccine is. Meanwhile only 138(33.7\%) agreed that MMR vaccine can also prevent mumps and rubella and 146(35.7\%) mothers indicated that two doses of MMR vaccines is recommended for children, one to be taken at 9months 234(57.2\%) and the other at 15months 179(43.8). In summary, only 39\% mothers had high knowledge of measles and MMR vaccine figure 3. Other information on knowledge of mothers on measles and MMR vaccine are in table 2, table 3, figure 1, 2 and 3. 
Table 2: Knowledge of Mothers on Measles

\begin{tabular}{|c|c|c|c|}
\hline Variables & $\begin{array}{l}\text { Yes } \\
\mathrm{N}=414 \\
\mathrm{~F}(\%) \\
\end{array}$ & $\begin{array}{l}\text { No } \\
\text { F (\%) }\end{array}$ & $\begin{array}{l}\text { I don't Know } \\
\text { F (\%) }\end{array}$ \\
\hline Do you know what measles is & $386(93.2)$ & $28(6.8)$ & $0(0.0)$ \\
\hline Measles is a viral infection & 302(72.9) & $65(15.7)$ & $47(11.4)$ \\
\hline Measles is a highly contagious infection & 330(79.7) & $19(4.6)$ & $65(15.7)$ \\
\hline Both adult and children can contact measles & $315(76.1)$ & $27(6.5)$ & $72(17.4)$ \\
\hline Can vaccinated individual contact measles & 124(30) & $205(49.5)$ & $85(20.5)$ \\
\hline Measles can be contacted through respiratory droplets & $160(38.6)$ & $155(37.4)$ & $99(23.9)$ \\
\hline Measles can be contacted through food & $86(20.8)$ & $260(62.8)$ & $68(16.1)$ \\
\hline $\begin{array}{l}\text { Measles can be contacted through non-practicing good hand } \\
\text { hygiene }\end{array}$ & $243(58.7)$ & $86(20.8)$ & $85(20.5)$ \\
\hline $\begin{array}{l}\text { Measles can be prevented through avoiding children from } \\
\text { coming in contact with children who are sick }\end{array}$ & $320(77.3)$ & $59(11.8)$ & $35(8.5)$ \\
\hline $\begin{array}{l}\text { Measles can be prevented through covering the nose and } \\
\text { mouth when coughing or sneezing }\end{array}$ & 197(47.6) & $116(28)$ & $101(24.4)$ \\
\hline Measles can be prevented through vaccination & $320(77.3)$ & $40(9.7)$ & $54(13)$ \\
\hline
\end{tabular}

\section{$217(52.4 \%)$ Source of Information on Measles}

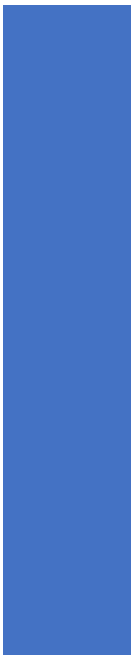

\section{$84(20.3 \%)$}

$22(5.3 \%)$

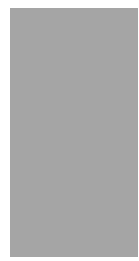

$69(16.7 \%)$

Figure 1: Source of information on measles

KEYS;

Family/friends

self experience

health workers

media/internet

I don't know/no information 
Table 3: knowledge of Mothers on MMR vaccine

\begin{tabular}{llll}
\hline Variables & Yes N=414 & $\begin{array}{l}\text { No } \\
\text { F (\%) }\end{array}$ & $\begin{array}{l}\text { I don't Know } \\
\text { F (\%) }\end{array}$ \\
\hline $\begin{array}{l}\text { Do you know MMR vaccine } \\
\text { Apart from measles, MMR can also prevent mumps and }\end{array}$ & $273(65.9)$ & $37(8.9)$ & $102(24.6)$ \\
rubella & $140(33.8)$ & $42(10.1)$ & $232(56)$ \\
Two doses of MMR vaccines is recommended for children & $149(35.9)$ & & \\
MMR vaccine should be taken at 9 months & $236(57)$ & $9(2.2)$ & $256(61.8)$ \\
MMR vaccine should be taken at 15 months & $181(43.7)$ & $13(3.1)$ & $165(39.9)$ \\
MMR vaccine is safe & $268(64.7)$ & $37(8.9)$ & $196(47.3)$ \\
MMR vaccine has side effects & $35(8.5)$ & $22(5.3)$ & $124(30)$ \\
Every individual can take MMR vaccine & $189(45.7)$ & $175(42.3)$ & $204(49.3)$ \\
\hline
\end{tabular}

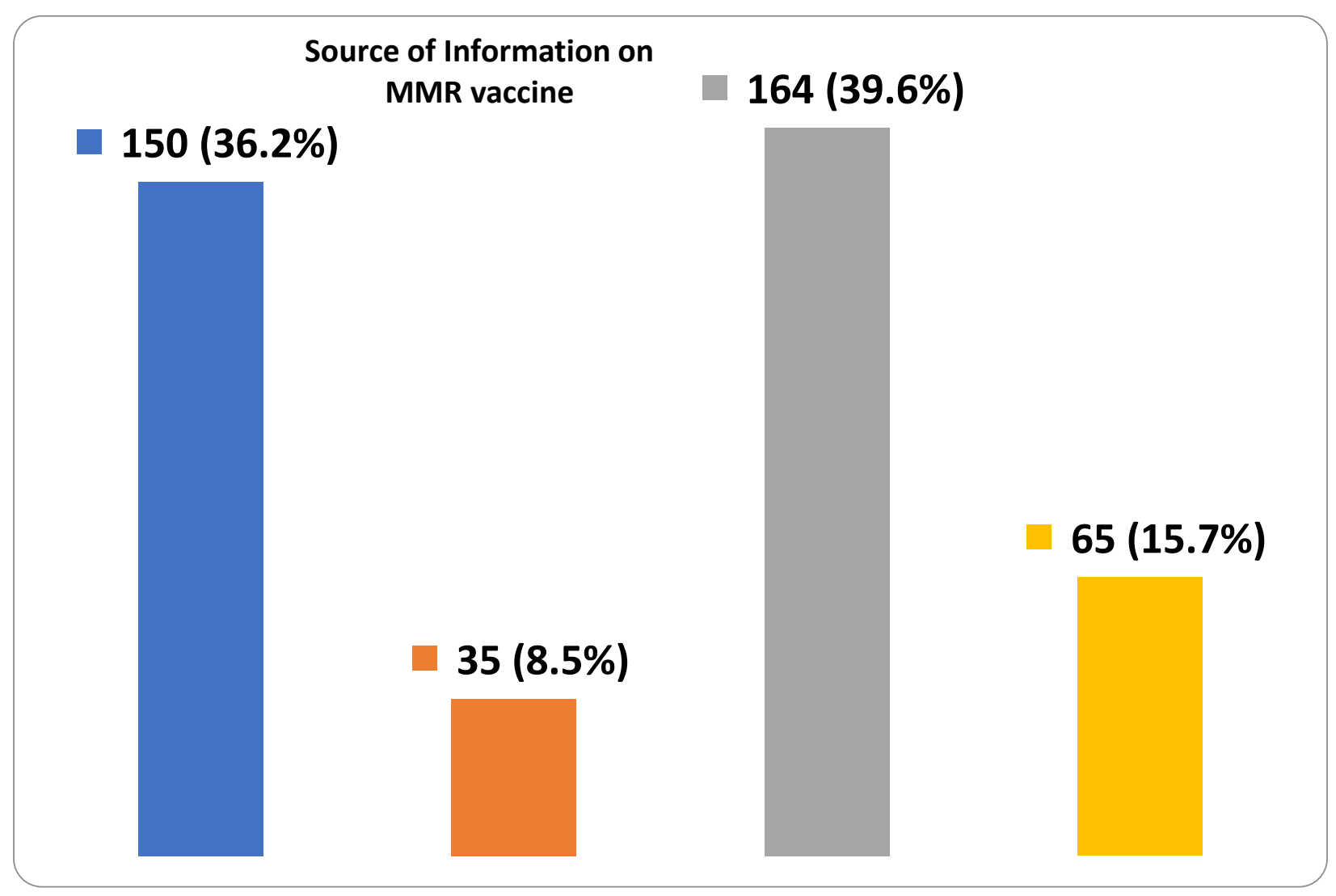

Figure 2: Source of Information on MMR vaccine

KEY;

health worker/ hospital

family/friends

internet/media/TV

No information 


\section{Summary of level of knowledge \%}

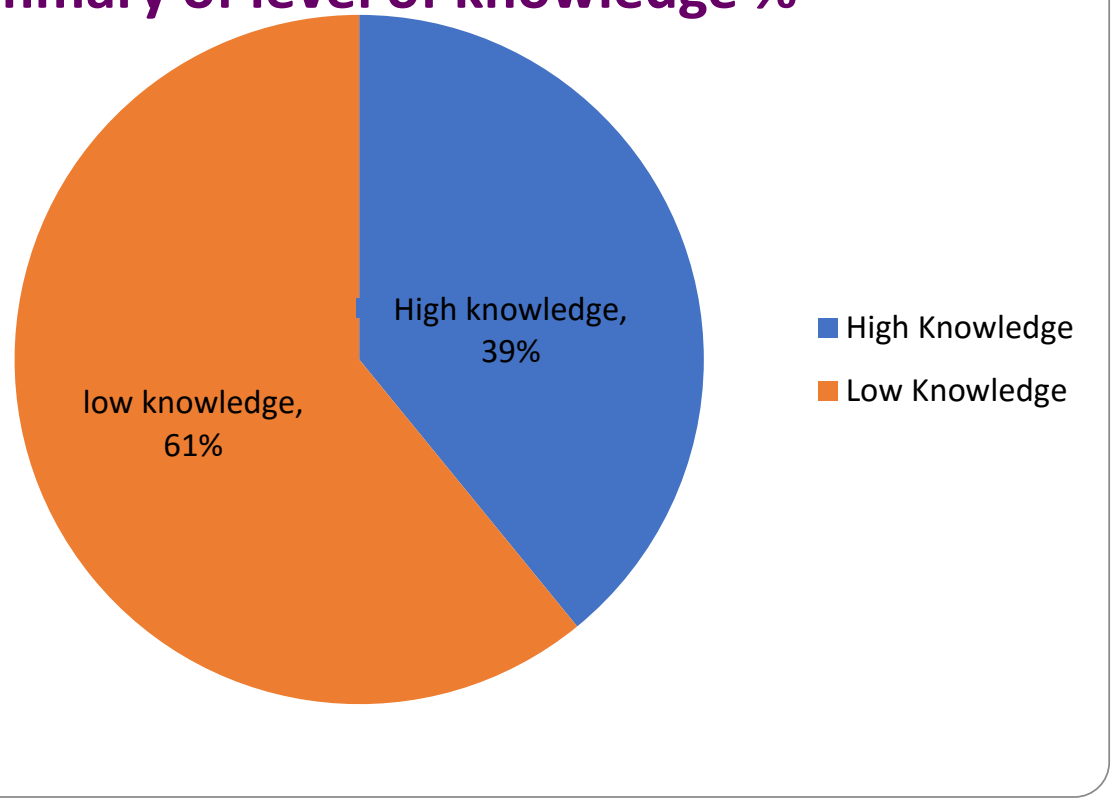

Figure 3: Summary on Level of Knowledge on Measles and MMR vaccine

\section{ATTITUDE OF MOTHERS TOWARDS MEASLES AND MMR VACCINE}

Table 5 reveals that majority of the mothers disagreed with negative worded statements, only $123(30.1 \%)$ and $111(27.1 \%)$ disagreed with the following statements respectively; every child hasmeasles during growing stage and whether a child receives MMR vaccine or not, if such will have measles, he will surely have it. In addition, majority agreed with almost all the positive statements, it is only the statement "Every child should be given 2 doses of MMR vaccine" that only $191(46.7 \%)$ agreed with. In summary $74.1 \%$ of the mothers had good attitude towards Measles and MMR vaccine figure 4. 
Table 4: Attitude of Mothers towards Measles and MMR vaccine

\begin{tabular}{llll}
\hline Variables & $\begin{array}{l}\text { Agreed N=414 } \\
\text { F (\%) }\end{array}$ & $\begin{array}{l}\text { Uncertain } \\
\text { F (\%) }\end{array}$ & $\begin{array}{l}\text { Disagreed } \\
\text { F (\%) }\end{array}$ \\
\hline Measles is not deadly & $192(46.4)$ & $47(11.4)$ & $175(42.3)$ \\
Measles cannot be prevented & $48(11.6)$ & $62(15)$ & $304(73.4)$ \\
MMR vaccine can cause death & $66(15.9)$ & $92(22.2)$ & $256(61.8)$ \\
MMR vaccine is harmful & $50(12.1)$ & $75(18.1)$ & $289(69.8)$ \\
There is no need to prevent measles & $61(14.7)$ & $50(12.1)$ & $299(72.2)$ \\
Every child have measles during growing stage & $127(30.7)$ & $161(38.9)$ & $126(30.4)$ \\
It is normal for children to have measles & $155(37.4)$ & $82(19.8)$ & $177(42.7)$ \\
Whether a child receives MMR vaccine or not, if such will & $118(28.5)$ & $181(43.7)$ & $115(27.8)$ \\
have measles, he will surely have it & & & \\
Measles is a communicable disease & $347(83.8)$ & $52(12.6)$ & $15(3.6)$ \\
Measles is a vaccine-preventable disease & $313(75.6)$ & $89(21.5)$ & $12(2.9)$ \\
MMR vaccine is safe & $349(84.3)$ & $53(12.8)$ & $13(3.1)$ \\
MMR vaccine is the best to prevent measles in every child & $267(64.5)$ & $125(30.2)$ & $20(4.8)$ \\
It is good to recommend others to vaccinate their children & $347(83.8)$ & $48(11.6)$ & $19(4.6)$ \\
against measles & & & \\
MMR vaccine can prevent outbreak of measles in the & $314(75.8)$ & $66(15.9)$ & $34(8.2)$ \\
community & & & \\
MMR vaccine reduces mortality rate from measles & $331(80)$ & $76(18.4)$ & $7(1.7)$ \\
Every child should be immunised against measles & $334(80.7)$ & $80(19.3)$ & $0(0.0)$ \\
Every child should be given 2 doses of MMR vaccine & $195(47.1)$ & $175(42.3)$ & $44(10.6)$ \\
\hline
\end{tabular}

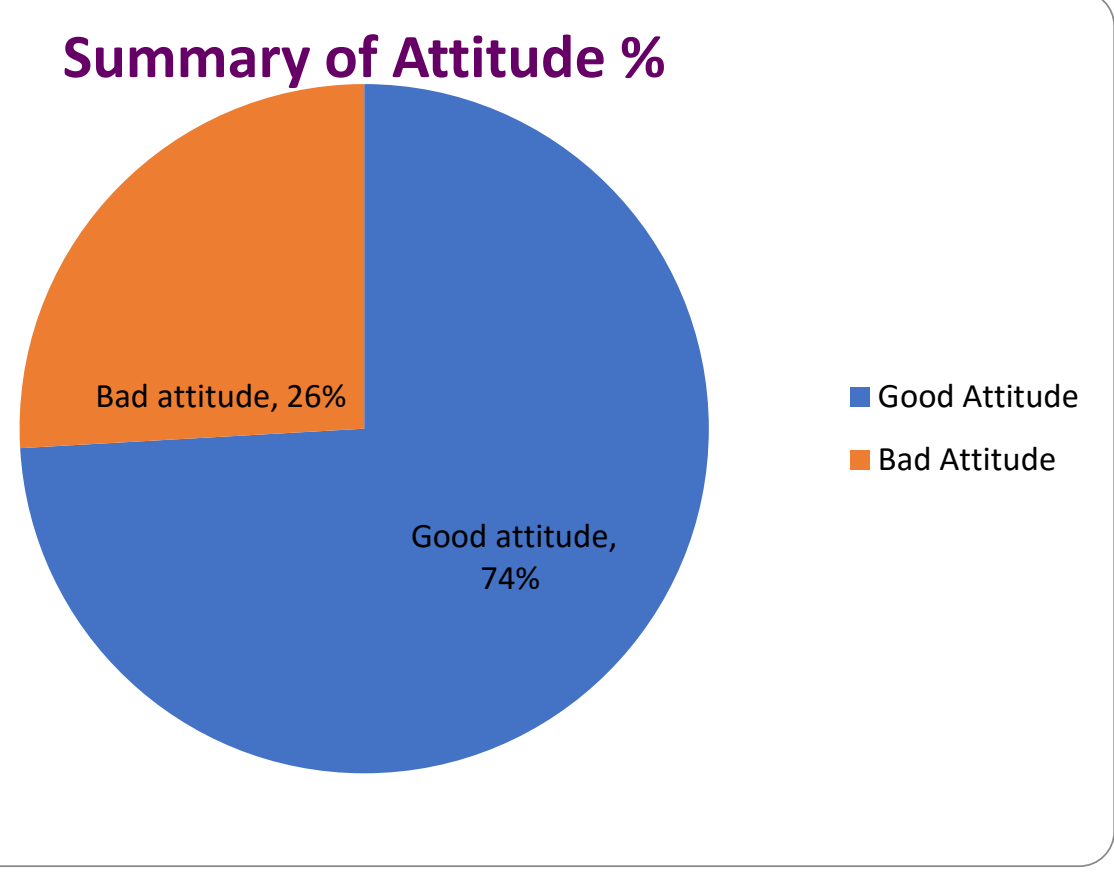

Figure 4: Summary on level of Attitude towards Measles and MMR vaccine

Table 5: Association of Socio Demographic variables with Attitude of Mothers 


\begin{tabular}{|c|c|c|c|c|}
\hline Variables & $\begin{array}{l}\text { Bad Attitude } \\
(\mathrm{N}=414)\end{array}$ & $\begin{array}{l}\text { Good Attitude } \\
(\mathrm{N}=414)\end{array}$ & $\chi^{2}$ & p-value \\
\hline \multicolumn{5}{|l|}{$\overline{\text { Age }}$} \\
\hline$<30$ years & 63 & 162 & 1.895 & 0.59 \\
\hline $31-40$ years & 33 & 106 & & \\
\hline $41-50$ years & 10 & 29 & & \\
\hline$>50$ years & 3 & 8 & & \\
\hline \multicolumn{5}{|l|}{ Educational Status } \\
\hline No education & 2 & 8 & 6.19 & 0.102 \\
\hline Primary & 11 & 15 & & \\
\hline Secondary & 38 & 122 & & \\
\hline Tertiary & 55 & 163 & & \\
\hline \multicolumn{5}{|l|}{ Occupation } \\
\hline Prof & 22 & 82 & 20.0 & 0.000 \\
\hline Non-Prof & 100 & 145 & & \\
\hline Unemployed & 40 & 27 & & \\
\hline \multicolumn{5}{|l|}{ Income } \\
\hline $\begin{array}{l}\text { High income/mth } \\
(100,000 \& \text { above })\end{array}$ & 80 & 189 & 5.9 & 0.009 \\
\hline $\begin{array}{l}\text { Low income } \\
\text { (Below } 100,000 \text { ) }\end{array}$ & & & & \\
\hline $\begin{array}{l}\text { (Below 100,000) } \\
\text { Parity }\end{array}$ & 31 & 114 & & \\
\hline Low & 100 & 291 & 23.0 & 0.000 \\
\hline
\end{tabular}

Table above showed that occupation $(\chi 2=20, \mathrm{P}=0.000)$, Income $(\chi 2=5.9, \mathrm{P}=0.009)$ and parity $(\chi 2=23, \mathrm{P}=0.000)$ are significantly with parity. Professionals' mothers, mothers with high income, and mothers with low number of deliveries had good attitude towards measles and MMR vaccine than their counterparts.

\section{DISCUSSION}

Measles is an acute and highly contagious viral disease of public health concern especially in developing countries. Several studies have been carried out on knowledge and attitude of women towards measles and vaccination in general. However, there is dearth information on knowledge and attitude of women towards measles in Nigeria out of which only few studies looked into the concepts of measles and MMR together.

Knowledge is a strong factor towards utilization of any health care services. Report revealed that in Ogun state, as at 2018 many children were not immunized against measles and it has been observed at community level that many mothers do not take their under-five children for vaccination against measles because of certain beliefs, superstitions and lack of adequate knowledge. Present study revealed that most of the mothers indicated that they knew what measles is. Majority of the participants recognized fever and rash as the signs of measles; which is in consistent with a study carried out in Australia and New Zealand by Brieger et al. (2017) which reported fever and rash as common signs and symptoms of measles. Many identified it as a viral infection that can be contacted from other children and also can be prevented via vaccination however, only few had adequate knowledge of its complications and mode of transmission. In addition, mothers indicated they knew what MMR vaccine is but only few knew that MMR vaccine can also prevent mumps and rubella this is in agreement with a study carried out in 
Brazilian city by Logullo et al. (2008) where 25 people said "There is no mumps vaccine". Furthermore, only few percentages of the participants knew two doses of MMR vaccine is required to prevent measles. These identified gaps affected their overall knowledge score on measles and MMR vaccine. This implies the need for Health Care providers to go beyond giving health education in health care setting. Efforts should be directed towards reaching out to mothers in their homes with adequate health information so that health knowledge will improve beyond what they acquired from friends and families.

Among the sources of information identified by mothers in current study, family and friends had the highest percentage while mass media and social media had the highest percentages for knowledge on MMR vaccine. Family and friends are strong significant orders in shaping individual view and improving individual understanding of certain concepts (Guo, 2019). Thus, public enlightenment on health issues remains a major tool in promoting and improving healthy preventive behaviours in the community at large (Ophori, et al. 2014; Cockcroft et al., 2015).

It is worth noting that majority of the respondents in the present study have a good attitude towards measles and MMR vaccine which is in consistent with a study carried out by Adefolalu et al. (2019) and a study by Oladepo et al. (2019) among mothers. Many of these mothers agreed that every child should be immunised against measles. This finding is in congruent with Weiss et al. (2016) study where many of the mothers agreed that it is good to vaccinate a child. However, some studies carried out in Bauchi and Cross rivers States Nigeria revealed negative attitudes among the mothers (Cockcroft et al., 2015). One of the key factors responsible for good attitude displayed by the present study participants was due to high percentage of mothers with lesser child bearing experience. Such mothers are most likely to show more positive attitude on issues relating to their newborn irrespective of their level of knowledge than the experienced mothers. These mothers tend to ask questions and seek for information about their child's health. Other significant factors associated with attitude are occupation and income. Professionals and mothers earning high income had good attitude towards measles and MMR vaccine than their counterparts. This seems to agree with Singh (2019) study among post-natal women in Malaysia where mothers' occupation is one of the significant factors associated with attitudes towards childhood vaccination.

\section{CONCLUSION}

In conclusion, mothers' knowledge on measles and MMR vaccine is quite inadequate. It is quite interesting to discover that majority of the mothers do not know MMR vaccine is given at 15 months and they do not know other diseases the vaccine prevents. This implies the need for nurses working with mothers to improve on their health educational program package based on the gaps identified. Nurses can make use of this health educational package in educating mothers be it in clinic or during community outreach programs. This health education can also be carried out via mass media and social media. This will help the more in broadening the understanding of mothers on measles and MMR vaccine which will help more in influencing their attitude towards the vaccine. This will consequently lead to increase in the number of children vaccinated against measles thus reducing the cases of measles with its complications and under five mortality rates in the nation. 


\section{CONFLICT-OF-INTEREST}

Authors declare that there is no competing or conflict of interest of any kind.

\section{ACKNOWLEDGEMENT}

Authors are grateful to colleagues that assisted in data collection and would also like to appreciate all participants.

\section{REFERENCES}

Abebe, A.M., Mengistu, T., \& Mekuria, A.D. (2019). Measles case, Immunization coverage and its determinant factors among 12-23 month Children, in BassonaWorenaWoreda, Amhara Region, Ethiopia. BioMed Central Research Notes, 12 (71). doi: 10.1186/s13104-019-4104-8

Adedokun, S., Uthman, O., Adekambi, V.,\& Wiysonge, C.S. (2017). Incomplete Childhood immunization in Nigeria: A multilevel analysis of individual and contextual factors. BioMed Central Public Health, 17(1):236. doi: $10.1186 / \mathrm{s} 12889-017-4137-7$

Adefolalu, O.A., Kanma-Okafor, O.J.,\& Balogun, M.R. (2019). Maternal knowledge, attitude and compliance regarding immunization of under five children in Primary Health centres Ikorodu Local Government Area, Lagos State. Journal of Clinical Sciences, 16 (1): 7-14.doi: 10.4103/jcls.jcls_55_18

Brieger, D., Edwards, M., Mudgli, P., \& Whitehall, J. (2017). Knowledge, Attitudes and Opinions towards Measles and the MMR Vaccine across two NSW cohorts. Australian and New Zealand Journal of Public Health, 41(6): 1753-6405. doi.: 10.1111/1753-6405.12720

Brinkchoff, T. (2020). City population Abeokuta south Local Government Area in Nigeria. http://citypopulation.de Centre for Diseases Control (CDC) (2021, January 26). What everyone should know.www.cdc.gov>vpd.mmr>public Chris-Otubor, G.O., Dangiwa, D.A., Ior, L.D., \&Anukam, N.C. (2015). Assessment of Knowledge, Attitudes and Practices of Mothers in Jos North Regarding Immunization. International organization of Scientific Research Journal of Pharmacy, 5(6): 34-45.https://iosrohr,org/papers/v516/H0506034045.pdf

Cockcroft, A., Usman, M.U., Nyamucherera, O.F., Emori, H., Duke, B., Umar, N.A., \& Anderson, N. (2015). Why children are not vaccinated against measles: A cross-sectional study in two Nigerian States. Archives Public Health, 72(48):2049-3248. doi: 10.1186/2049-3258-72-48

Geier, D.A., Kern, J.K., \& Geier, M.R. (2019). Childhood MMR vaccination \& the Incidence rate of Measles infection: A ten year longitudinal cohort study of American children born in 1990s. BioMed Central Pediatric. 19, 325. doi: 10.1186/s12887-019-1710-5

Guo, K. (2019). How do family, peers influence us? Retrieved on $18^{\text {th }}$ November, 2019 from: https://www.statesmanshs.org/913/features/how-do-family-peers-influence-us/ 
Higuera, V. (2019). Everything you need to know about measles. Retrieved $21^{\text {st }}$ August, 2019 from: https://www.healthline.com/health/measles

Ibrahim, B.S., Usman, R., Yahaya, M., Datti, Z., Okunromade, O., Abubakar, A.A. ,\& Nguku, P.M. (2017). Burden of measles in Nigeria: A five-year review of cases-based surveillance data, 2012-2016. The Pan African Medical Journal ,32 (5). https://dx.doi.org/10.11604/pamj.supp.2019.32.1.13564

Israel, G.D. (2003). Determining Sample Size. University of Florida, IFAS extension. Retrieved June 2003, from https//www.tarleton.edu

Logullo, P., Carvallo, H.B., Saconi, R., \& Massad, E. (2008). Factors affecting compliance with the Measles vaccination schedule in a Brazillian city. Sao Paulo Medical Journal, 1269(3):1516-3180. doi:10.1590/S1516-31802008000300006

Oladepo, O., Dipeolu, I.O., \& Oladunni, O. (2019). Nigerian rural mothers knowledge of routine childhood immunizations and attitudes about use of reminder text messages for promoting timely completion. Journal of Public Health Policy, 40(4): 459-477.https://pesquisa.bvsalud.org/portal/resource/pt/mdl-31427672

Ophori, E.A., Tula, M.Y., Azih, A.V., Okojie, R., \& Ikpo, P.E. (2014). Current Trends of Immunization in Nigeria: Prospect and Challenges. Tropical med Health, 14(2): 67-75. doi: 10.2149/tmh.2013-13

Ramadan, H. A., Soliman, S.M., \& Abd El- kader, R.G. (2016). Knowledge, Attitude, and Practice of Mothers toward Childrens Obligatory Vaccination. International organization of scientific research Journal of Nursing and Health Science, 5(4) 22-28. doi: 10.9790/1959-0504022228

Ross, C.H. (2017). The Measles, Mumps \& Rubella (MMR) Vaccine. Retrieved on 22 $2^{\text {nd }}$ December, 2017 from: https://embryo.asu.edu/pages/measles-mumps-and-rubella-mmr-vaccine

Siddiqui, N.S., Gaikwad, A.K.,\& Kuril, B.M. (2017). Is Mothers Knowledge and Practice regarding Childhood immunization compliant with Immunization completeness. International Journal of Community Medicine Public Health, 4(3):775-780. doi: 10.18203/2394-6040.ijcmph20170757

Singh, H.K.B., Badgujar, V.B., Yahaya,D.A., Sami, F.M., Badgujar, S., Govindan, S.N., \& Ansari, M.T. (2019). Assessment of Knowledge and Attitude among Postnatal mothers towards Childhood vaccine in Malaysia. Human accines and immunotherapeutics, 15(11),2544-2551, https://doi.org/10.1080/21645515.2019.1612666

Taiwo, M.O., Adebari, H.O.,\& Adebayo, O.S. (2018). Declining Maternally-Derived Measles Antibodies in Infants and Nursing Mothers in Nigeria: A Review. Sydney Organ journal of Immunology, 6(1): 1-7. doi: 10.15226/2372-0948/6/1/00164 
Verulava, T., Jaiani, M., Lordkipanidze, A., Jorbenadze, R., \& Dangadze, B. (2019). Mothers' Knowledge and Attitude towards child immunization in Georgia. The Open health journal, 12, (232-237). doi: $10.2174 / 1874944501912010232$

Weiss, C., Schropfer, D., \& Merten, S. (2016). Parental Attitudes towards Measles Vaccination in the Canton of Aargau, Switzerland: A latent class analysis. BioMed Central Infectious Disease, $16,400$. doi:10.1186/s12879-016-1747-0

World Health Organization, (2019). Measles. Retrieve on $5^{\text {th }}$ December, 2019 from https://www.who.int

World Health Organization, (2020). Worldwide measles deaths climb 50\% from 2016 to 2019 claiming over 207500 lives in 2019. Retrieved on $12^{\text {th }}$ November, 2020 from https://www.who.int

Zahrei, S.M., Gouya, M.M., Mohammad, M., Tabatabaei, S.M., Zanganeh, M., Zareban, I., \& Khorram, A. (2017). A Survey on Measles and Rubella Supplementary Immunization Activities (SIAs) in Iran. Health Scope, 6(4): e64184. doi: 10582/jhealthscope.64184 